\title{
Gammelt og nyt brydes
}

af Poul Andersen

Redaktionen af Sønderjyske Årbøger har undfanget den idé, at tidligere formænd skulle bringe et bidrag til jubilæumsårbogen og på den måde være med til at tegne et billede af Historisk Samfunds udvikling i de sidste ca. 40 år. Hvordan denne udvikling er forløbet, vil de medlemmer, der har årbøgerne stående på reolen, kunne læse i årsberetningerne. Nu er det måske ikke lige det, der kommer ind under begrebet morskabslæsning. Men disse beretninger giver år for år en oversigt over "Rigets stilling «. De giver nøgtern besked om initiativer, udgivelser (i min tid fra 1980 til 1986 i alt 19), om okonomien, ændringer i styrelsen med mere. Alt dette er det vigtigt at fastholde, hvad det da også er blevet. Det er Historisk Samfunds historie.

Som sagt, det findes på tryk, og det skal derfor ikke gentages her. Derimod kan det være rimeligt at samle opmærksomheden om et enkelt punkt, som kun fylder lidt $\mathrm{i}$ årsberetningerne - nemlig forholdet mellem den gamle forening Historisk Samfund - og de nydannede lokalhistoriske foreninger og arkiver, som slog igennem netop i min formandstid.

En væsentlig del af faderskabet til den nye bølge må tillægges Historisk Samfund. I 1956 var Peter Kr.Iversens dygtige organisationstalent kommet til udtryk ved oprettelsen af amtskredse med tillidsmænd i næsten hvert sogn. I henhold til Historisk Samfunds vedtægter skulle foreningen ud over at udgive Sønderjyske Årbøger og Sønderjysk Månedsskrift »- udøve en tilskyndende og vejledende virksomhed over for historisk, særlig lokalhistorisk arbejde." Og netop dette kunne ske gennem amtskredsene. Den enkelte amtskreds skulle "vække og nære den historiske sans, især ved lokalhistoriske foredrag, om muligt i samarbejde med stedlige foredragsforeninger, ved at arrangere egnsog byvandringer og ved at søge oprettet sognehistoriske grupper.« Et langt stykke blev disse mål også nået inden for amtskredsenes rammer.

\section{Nybrud på den lokalhistoriske ager}

Men i 1980 var "pusten« gået lidt af amtskredsenes virke. Den lokalhistoriske interesse var stadig levende, ja den var måske levende som aldrig før, men den fandt ikke så meget udtryk gennem amtskredsene som gennem de nye 
selvstændige sogne-, egns- og hjemstavnsforeninger. Fra slutningen af 1970'erne myldrede de frem - og i tilknytning til mange af foreningerne oprettedes også arkiver. Denne grøde i det lokalhistoriske arbejde opstod sikkert i mangt og meget på grundlag af den sæd, som var spredt gennem Historisk Samfunds amtskredse, og drivkraften i de nye foreninger var ofte medlemmer af Historisk Samfund. Foreningernes formænd var tillige ofte ledere af de lokale arkiver.

Disse foreninger og arkiver fik stor tilgang af medlemmer. Som amtsorganisation blev "Lokalhistoriske Arkiver og Samlinger i Sønderjylland« (LASS) stiftet i december 1979, og sammenslutningens medlemstal voksede hurtigt. I 1981 var 32 arkiver og samlinger tilsluttet. I 1985 var tallet vokset til 40. Siden er udviklingen fortsat, således at mere end 50 foreninger og arkiver i dag er tilsluttet LASS. Derudover er der for tiden omkring 10 lokalhistoriske foreninger og arkiver, som ikke er medlem af amtsorganisationen. Et interessant tal kommer frem, når det i skrivende stund konstateres, at af LASS's medlemsskare på 55 er kun 24 arkiver. Resten er sogne- og hjemstavnsforeninger, lokalhistoriske foreninger og lignende. Det viser, at det er lokalhistorien, som er det primære.

Tallene viser således allerede $i$ tiden frem til 1985 en vældig vækst på den lokalhistoriske arbejdsmark. Flere af foreningerne var af imponerende omfang. 2-300 medlemmer var ret almindeligt, og en enkelt forening havde over 500 medlemmer. I Sønderjyske Årbøger viste udviklingen sig ved at afsnittene om det lokalhistoriske arbejde fyldte stadig mere. I 1980 var et par sider nok, i dag er der stof til at fylde 20 sider.

Det har været en fornøjelse at se dette lokalhistoriske arbejde vokse op fra en lille halv snes foreninger/arkiver til nu omkring 50, og ligeledes den begejstring der arbejdes med. Af og til kan man næsten frygte, at det går for stærkt. Man må håbe, at begejstringens morgenrøde ikke blegner.

Men arbejdet bliver der $\mathrm{i}$ arkiverne, ofte under primitive forhold og med beskeden økonomisk støtte, eller helt uden, og arbejdet udføres de fleste steder uden honorar. En eller flere gange ugentlig samles en lille flok for at registrere billeder, ejendomspapirer, dag- og regnskabsbøger m.m. Og på andre dage aflægges besøg hos sognets befolkning, der på lofter og i skabe finder arkivalier og billeder, der er med til at belyse fortiden.

Og så kommer der besøg, folk der vil have oplysninger om deres slægt, og fotokopier af kirkebøger og skyld- og panteprotokoller granskes, så man kan give de fornødne svar. Så vidt, så godt.

Skal man betragte det lidt rationelt, ville det nok være fornuftigt at samle de mindre arkiver/foreninger inden for kommunerne. Det ville uden tvivl være en fordel både arbejdsmæssigt og økonomisk. Men her støder man på 
udforme samarbejdet med de nye foreninger? Hvordan kunne man på én gang støtte de mange nye initiativer, som jo lå helt $\mathrm{i}$ forlængelse af Historisk Samfunds formålsparagraf og samtidig sikre fortsat tilgang af medlemmer til Historisk Samfund? Hvilken rolle skulle amtskredsene indtage fremover, og hvordan kunne man evt. sikre, at de genvandt pusten? Om disse og lignende spørgsmål blev der debatteret livligt i årene frem til 1985.

Forskellige initiativer blev taget for at styrke kontakten mellem Historisk Samfund og de nye foreninger. I vinteren 1981-82 tog vi fat på årlige møder i amtskredsene for repræsentanter fra de lokale historiske foreninger, arkiver og samlinger. Det var tanken på denne måde at skabe et forum for udveksling af erfaringer og måske at yde råd og hjælp i det påbegyndte arbejde. Disse fællesmøder blev positivt modtaget og er siden blevet en fast tradition.

Alligevel måtte vi konstatere, at føringen på det lokale plan nok i nogen grad var overgået til de lokalhistoriske foreninger. De fik flere medlemmer, mens Historisk Samfunds medlemstal stagnerede. Det var ikke en selvfølge at kombinere medlemsskab af den lokale forening og amtssamfundet. Der lød endda stemmer om, at Historisk Samfund mere og mere var ved at blive blot et udgiverselskab og bogforlag - med svigtende jordforbindelse.

I erkendelse af den nye udvikling optog Historisk Samfund fra $1986 \mathrm{i}$ stigende grad beretninger fra de lokale foreninger og arkiver i Sønderjyske Årbøger for på den måde at informere om det lokalhistoriske arbejde. I 1985 blev der desuden nedsat et udvalg, som skulle drøfte muligheden for et nøjere samarbejde med de lokale kræfter. Der blev tænkt mange tanker og taget en del intiativer. Forhandlinger blev også indledt, men de løb ud i sandet. De mange og meget forskelligartede foreninger foretrak at arbejde selvstændigt på egne præmisser.

Personligt vil jeg vove at stille det spørgsmål, om Historisk Samfund forsømte at kende sin besøgelsestid for et koordinerende samarbejde med alle de nye foreninger. Jeg er stadig af den mening, at her burde vor gamle forening have været "førerhund «, og ud fra sin erfaring med historisk arbejde have medvirket til at gøre det lokalhistoriske arbejde mere ensartet og samlet om et fælles mål.

Mine visioner om et koordinerende samarbejde og højnelse af niveauet $i$ det lokalhistoriske arbejde blev ikke til virkelighed. Dette resultat kan vurderes både positivt og negativt $-\mathrm{i}$ alt fald må det konstateres, at en broget mangfoldighed præger det lokalhistoriske arbejde og dets synlige resultater.

Men det må også konstateres, at der i dag, kun få år efter, for alvor er begyndt at ske noget: I 1985 var man i den heldige situation, at der kunne oprettes en stilling som leder af Historiske Samlinger og tillige som lokalhistorisk konsulent. Konsulenten fik til opgave at udføre netop det arbejde i retning 
af en højnelse af niveauet, som er omtalt i det foregående. Ved besøg i arkiver og samlinger skal han være rådgiver og inspirator.

Vi har lov til at tro - i alt fald håbe - på en stedse større folkelig opbakning i det lokalhistoriske arbejde, så der ikke kun bliver tale om en lille gruppe, som plejer en hobby. Vi kan håbe på, at arbejdet udvikles, så arkivalierne ikke blot flyttes fra et støvet loft eller en kommodeskuffe til dvale i et arkiv.

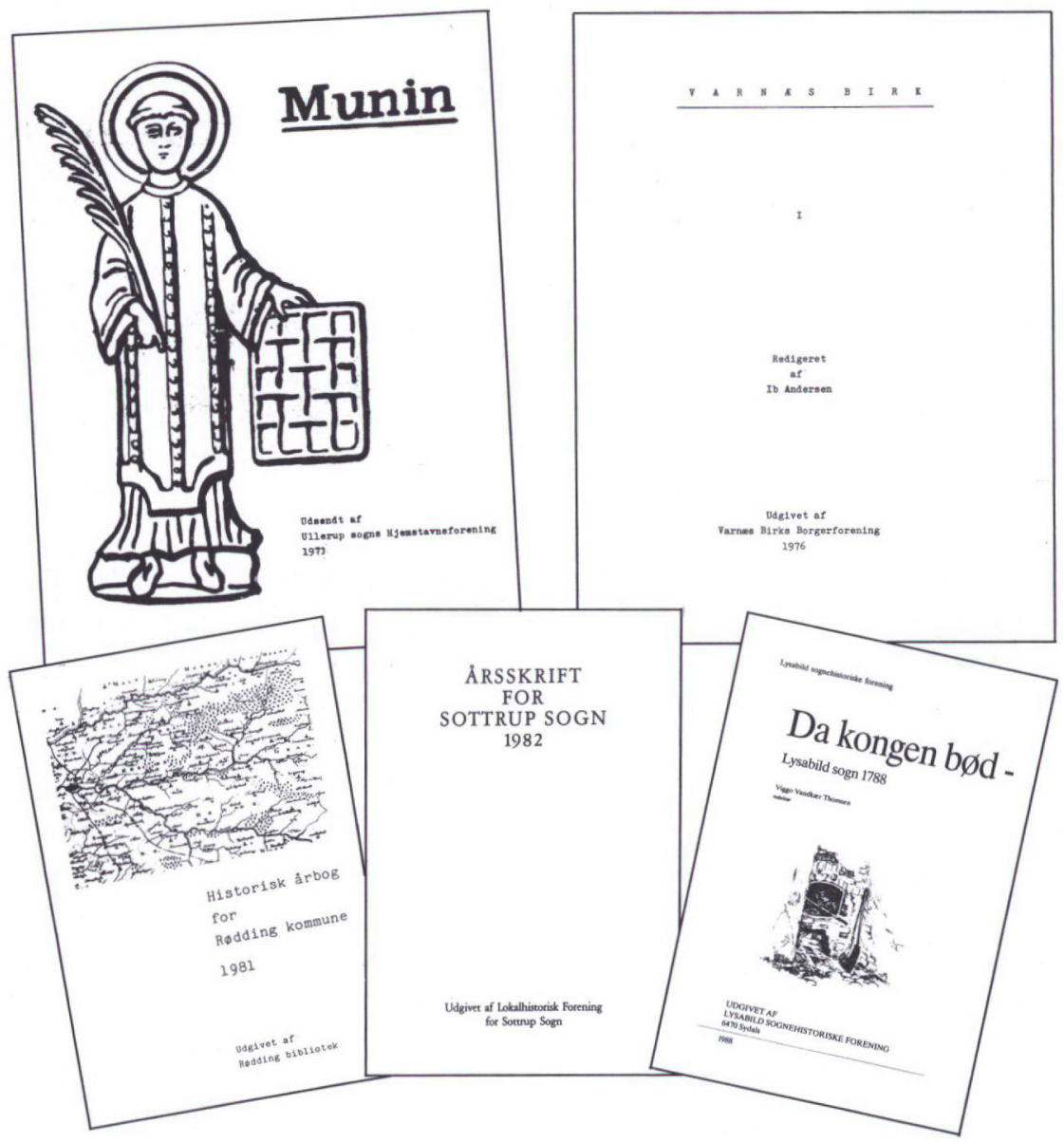

Mange af de lokalhistoriske foreninger og arkiver udgiver publikationer, enten med faste mellemrum som drsskrifter eller ved jubilaer og andre markedage. Nogle enkelte skriftrakker startede i 1960 'erne, flere $i 1970$ 'erne, og i dag er rakken af udgivelser lang. Her vises blot nogle få eksempler pd de mange publikationer $i$ det lokalhistoriske landskab. 
Målet er jo, at materialet bliver udnyttet i større eller mindre publikationer til at fortælle sognenes historie og dermed vor landsdels historie. Der bliver allerede ydet en betydningsfuld indsats på dette felt. Og endnu mere kan gøres. For rigshistorien kan slet ikke undvære lokalhistorien. 